https://dx.doi.org/10.4314/ijs.v20i2.15

Ife Journal of Science vol. 20, no. 2 (2018)

\title{
IMPACT OF SMOKING TECHNIQUES AND STORAGE CONDITIONS ON MICROBIAL SAFETY AND STABILITY OF CATFISH (Clarias gariepinus)
}

\author{
* $^{1}$ Salaudeen, M. M. and $^{2}$ Osibona, A. O. \\ ${ }^{1}$ Nigerian Institute for Oceanography and Marine Research, 12729 Victoria Island, Lagos, Nigeria \\ ${ }^{2}$ University of Lagos, Department of Marine Sciences, Akoka, Lagos, Nigeria \\ *Corresponding author's e-mail: salaudeen06@yahoo.com, salaudeenmm@niomr.gov.ng
}

(Received: 28 ${ }^{\text {th }}$ May, 2017; Accepted: 26 ${ }^{\text {th }}$ May, 2018)

\section{ABSTRACT}

\begin{abstract}
Microbial spoilage is one of the causes of quality deterioration of smoked catfish during storage. The impact of smoking techniques and storage conditions on the quality of smoked catfish were determined. Smoked dried catfish were produced using traditional smoking kiln (44-gallon drum kiln) and an improved smoking kiln from Nigerian Institute for Oceanography and Marine Research (NIOMR). The smoked dried catfish were packed in polythene bags and stored at ambient $\left(30 \pm 3^{\circ} \mathrm{C}\right)$, refrigerated $\left(4 \pm 1^{\circ} \mathrm{C}\right)$ or frozen at $\left(-18 \pm 2^{\circ} \mathrm{C}\right)$ for 12 weeks. The moisture content and acidity $(\mathrm{pH})$ of the smoked fish products fluctuated during the storage period. Smoking reduced the total viable count $($ TVC) of the microorganisms significantly $(\mathrm{P}<0.05)$ from 5.71 to between 3.18 and $3.93 \log \mathrm{CFU} / \mathrm{g}$ for traditionally smoked and improved kiln smoked fish samples respectively. The microbial total viable count (TVC) of the stored smoked fish products increased as the storage period increased, the frozen stored smoked fish products had the highest TVC followed by the refrigerated stored smoked fish products and the ambient stored smoked fish products had the least TVC but there was no significant difference $(\mathrm{P}>0.05)$ among the storage conditions studied. The stored smoked fish products were acceptable up to $8^{\text {th }}$ week storage period based on microbial load. Gram negative organisms, Pseudomonas sp. and Aeromonas sp. were the bacteria identified while Penicillium sp. and Aspergillus niger were the fungi identified in the smoked fish products during the storage period. Microbial safety and shelf life of stored smoked catfish depends on the smoking technique adopted, storage condition and duration of storage.
\end{abstract}

Keywords: Catfish, Smoked fish, Ambient temperature, Refrigerated, Microbial loads

\section{INTRODUCTION}

The African catfish, Clarias gariepinus, is the most important tropical catfish species for aquaculture. It is easily cultured in Nigeria and of great economic interest. Nigeria produce over 250,000 tonnes of catfish annually, which makes Nigeria largest producer of catfish in Africa (FDF, 2014). Catfish is generally consumed fresh, a good percentage is also consumed smoked in Nigeria.

Smoking is one of the oldest methods used to process and preserve fish (Swastawati et al., 2000; Simko, 2002; Stołyhwo and Sikorski, 2005). Smoking can halt the formation of toxins and reduce the growth of bacteria due to lower water activity as a result of smoking in addition to salting and drying which create a physical surface barrier (Rervik, 2000). The salt content, duration and temperature of smoking, density of smoke and component of smoke affect the presence and composition of spoilage and pathogenic microflora of the smoked product (Kolodziejska et al., 2002).
Depending on the way smoke gets into products, smoking can be categorized accordingly: the traditional technique - where the smoke is formed directly by burning chips or sawdust from firm wood in the oven, wood log, and locally available materials such as coconut husk (Stołyhwo and Sikorski, 2005; Visciano et al., 2008); or new technique - by using an improved traditional smoking technique, mechanised smoking technique where the smoke generator is separated from the smoke chamber and there is no direct firing of the smoked products. The improved and mechanised smoking techniques use charcoal and smoke derivatives such as liquid smoke and powder smoke as the source of smoke flavour.

The commonly used smoking technique in Lagos, Nigeria is the 44-gallon drum kiln (Adeyeye et al., 2015) while the Nigerian Institute for Oceanography and Marine Research (NIOMR) smoking kilns have been adopted for use in over 30 states out of the 36 states in Nigeria and neighbouring countries such as Benin republic, the Gambia and Cote $\mathrm{d}$ voire. NIOMR improved 
smoking kilns have the support of international agencies such as Food and Agriculture Organization (FAO) of the United Nations, West Africa Agricultural Productivity Programs (WAAPP) and United States Agency for International Development (USAID). NIOMR smoking kilns have been designed to address the disadvantages of the traditional smoking kilns/ techniques (NIOMR, 2016).

The processing of a fish species inevitably entails a storage period for the finished product prior to marketing and consumption. Since fish are composed of perishable nutrients, storage period should be kept to a minimum with adequate storage conditions provided so as to prevent deteriorative changes occurring through oxidative damage and microbial infestation. The most important environmental factors governing the storage or shelf life of fish are ambient temperature and humidity. These factors dictate the rate at which chemical and microbial changes take place (Daramola et al., 2007).

The impact of the commonly used traditional smoking kiln (44-gallon drum kiln) and improved smoking kiln by NIOMR at different storage times and conditions (such as ambient, refrigerated and frozen conditions) on the microbial safety and stability of smoked catfish (Clarias gariepinus) has not been reported.

\section{MATERIALS AND METHODS Sample Collection, Smoking, Packaging and Storage}

Fifty kilograms $(50 \mathrm{~kg}$ ) of live catfish (each individual fish weighing $350 \mathrm{~g}$ to $450 \mathrm{~g}$ ) were purchased from Biotechnology Department, Nigerian Institute for Oceanography and Marine Research (NIOMR), Lagos, Nigeria. It was randomly divided into two halves and smoked by adopting two smoking techniques. One half was smoked using 44-gallon drum kiln that uses wood, at a temperature of $55-145{ }^{\circ} \mathrm{C}$ for $15 \mathrm{~h}$ and the second half was smoked using NIOMR kiln with charcoal at a temperature of $55-180^{\circ} \mathrm{C}$ for $11 \mathrm{~h}$. The smoked catfish from each techniques were cooled, packed in polythene bags, divided into three parts and stored for 12 weeks at three different temperature conditions: ambient $(30 \pm 3$ $\left.{ }^{\circ} \mathrm{C}\right)$, refrigerated $\left(4 \pm 1{ }^{\circ} \mathrm{C}\right)$ or frozen $\left(-18 \pm 2{ }^{\circ} \mathrm{C}\right)$.
Samples were drawn every two weeks for analysis.

\section{Moisture Determination}

Moisture content was determined by difference in weight of the homogenised samples before and after drying for $24 \mathrm{~h}$ in electronic oven at a temperature of $104 \pm 2{ }^{\circ} \mathrm{C}$ (AOAC 1994).

\section{Hydrogen ion ( $\mathrm{pH}$ ) Determination}

The $\mathrm{pH}$ of fresh and dried samples was measured by the method of Bragadottir et al., (2007). $5 \mathrm{~g}$ of fresh samples was measured directly while $5 \mathrm{~g}$ of dried samples was mixed with $20 \mathrm{ml}$ of deionised water, stirred for 5 mins prior to measurement with combined electrode SE 104- Mettler Toledo, Knick Berlin Germany connected to a portable $\mathrm{pH}$ meter.

\section{Microbial Analysis}

Isolation Technique: Fresh and smoked catfish samples were analysed for the presence of pathogens. A swab of the skin and gut of the fresh catfish samples were taken with sterile swab stick and $1 \mathrm{~g}$ representative sample was obtained aseptically from the loin muscle of the smoked catfish samples. The samples were ground and serial dilutions $\left(10^{-1}-10^{-4}\right)$ of the homogenized samples were made using sterile distilled water and plated out on seven (7) different culture media; nutrient agar (NA) was used to determine the total viable count (TVC) of bacteria, potato dextrose agar (PDA) and malt extract agar (MEA) were used to detect the presence of fungi and moulds, Salmonella-Shigella Agar (SSA) was used to detect the presence of Salmonella and Shigella, manitol salt agar was used to detect Staphylococcus colonies, lactose broth and eosine methylene blue (EMB) agar were used to detect the presence of coliforms, while thiosulphate citrate bile salt (TCBS) agar was used to detect the presence of Vibrio. The plates were incubated at room temperature $\left(30^{\circ} \mathrm{C}\right)$ for fungal isolates and $35^{\circ} \mathrm{C}$ for bacteria isolates (Harrigan, 1998; Joanne et al., 2008).

Identification of Isolates. Pure bacterial isolates were identified through their microscopic and biochemical characteristics, while the pure fungi isolates were identified using their cultural/microscopic characteristics (Holt, 1994; Joanne et al., 2008). 


\section{RESULTS}

The effect of two smoking techniques and storage conditions on the microbial quality of smoked catfish were examined during 12 weeks storage period under ambient, refrigerated and frozen storage conditions. The moisture content of the fresh sample was significantly reduced after smoking and there was also a significant reduction in the moisture content of improved kiln smoked catfish (IKSC) to that of traditionally smoked catfish (TSC) as presented in table 1. There was also a significant difference in the hydrogen ion $(\mathrm{pH})$ of the fresh, TSC and the IKSC, the $\mathrm{pH}$ fluctuated during the storage period as shown in table 2.

The total viable count (TVC) of fresh fish sample was $5.71 \log \mathrm{CFU} / \mathrm{g}$ and smoking was able to reduce the TVC to $3.18 \log \mathrm{CFU} / \mathrm{g}$ and $3.93 \mathrm{log}$ $\mathrm{CFU} / \mathrm{g}$ for traditionally smoked samples and improved kiln smoked samples respectively as shown in table 3. The samples smoked traditionally with wood showed greater reduction in the TVC of $3.18 \log \mathrm{CFU} / \mathrm{g}$ than samples smoked with improved kiln that use charcoal with TVC of $3.93 \log$ CFU/g as shown in table 3. The total viable count increased during storage for the fish products smoked by the two techniques in all the storage conditions up to $8^{\text {th }}$ week storage period as shown in table 3. It was also observed that the TVC of the smoked samples from the two techniques stored in the freezer had higher or equal to TVC of smoked samples stored in the refrigerator and ambient condition up to week 8 storage period. The refrigerated samples had TVC higher or equal to the TVC of samples stored at ambient condition up to $8^{\text {th }}$ week storage period. The order of TVC for both smoking techniques were frozen $\geqslant$ refrigerated $\geqslant$ ambient up to $8^{\text {th }}$ week storage period. It was also observed that at week 10 and 12 storage periods, smoked fish products from the two smoking techniques stored at ambient and refrigerated conditions respectively had TVC too numerous to count (TNTC) at dilution seven (table 3). Also, it was observed that after week 8 storage period, the smoked fish products stored in the frozen condition had reduction in TVC up to the end of the $12^{\text {th }}$ week storage period.

There was no yeast and mould growth in the freshly smoked (week 0) fish products. The yeast and mould growth identified in the study were Penicillium sp and Aspergillus niger, their load ranged between 1.00 and $2.55 \log \mathrm{CFU} / \mathrm{g}$ during the storage period and by the $10^{\text {th }}$ and $12^{\text {th }}$ week of storage, the ambient and refrigerated stored samples from the two smoking techniques had TNTC respectively as presented in table 3 . The effects of smoking techniques and storage conditions on yeast and mould growth had no clear significance as presented in table 3 . 


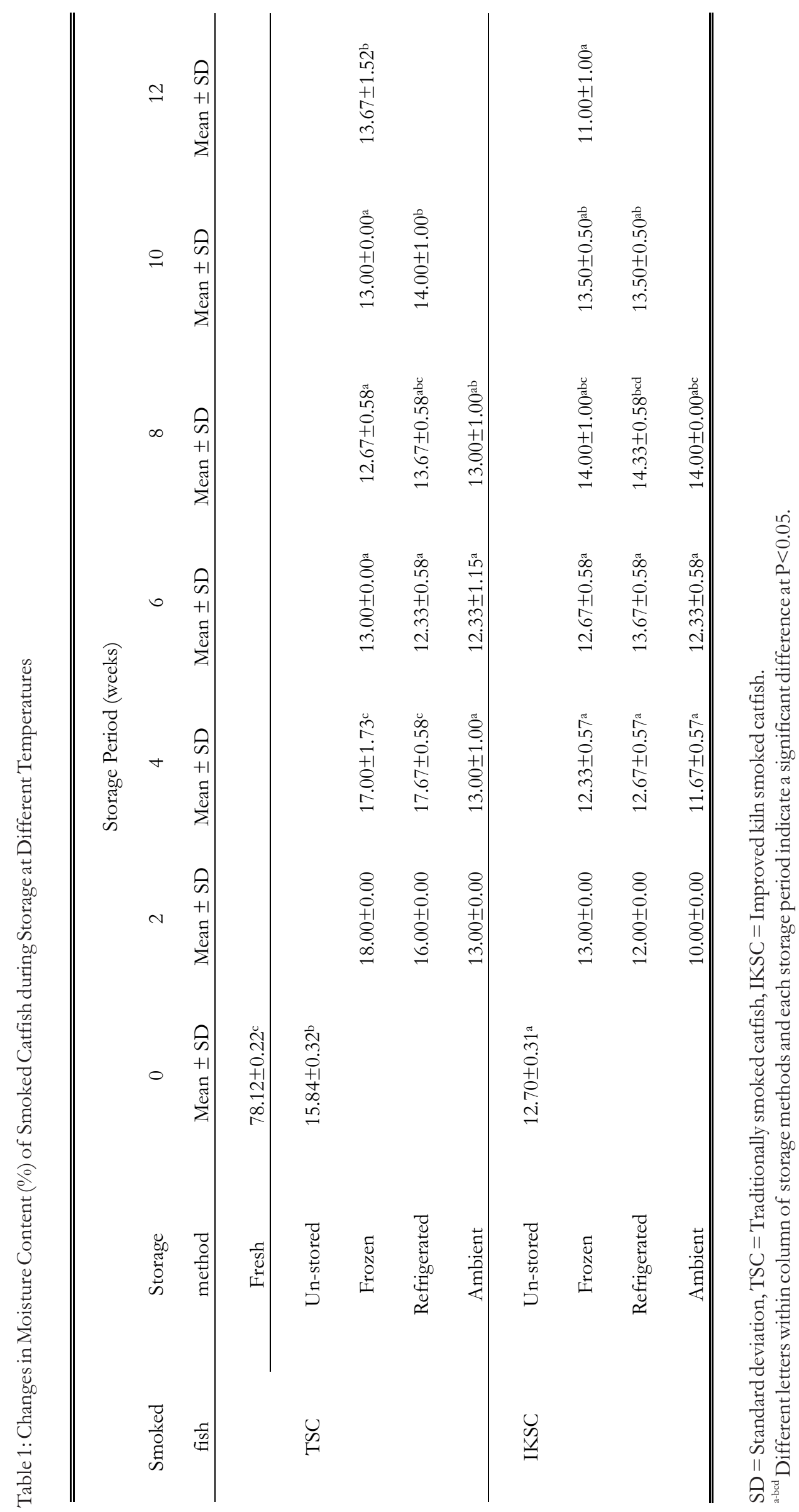




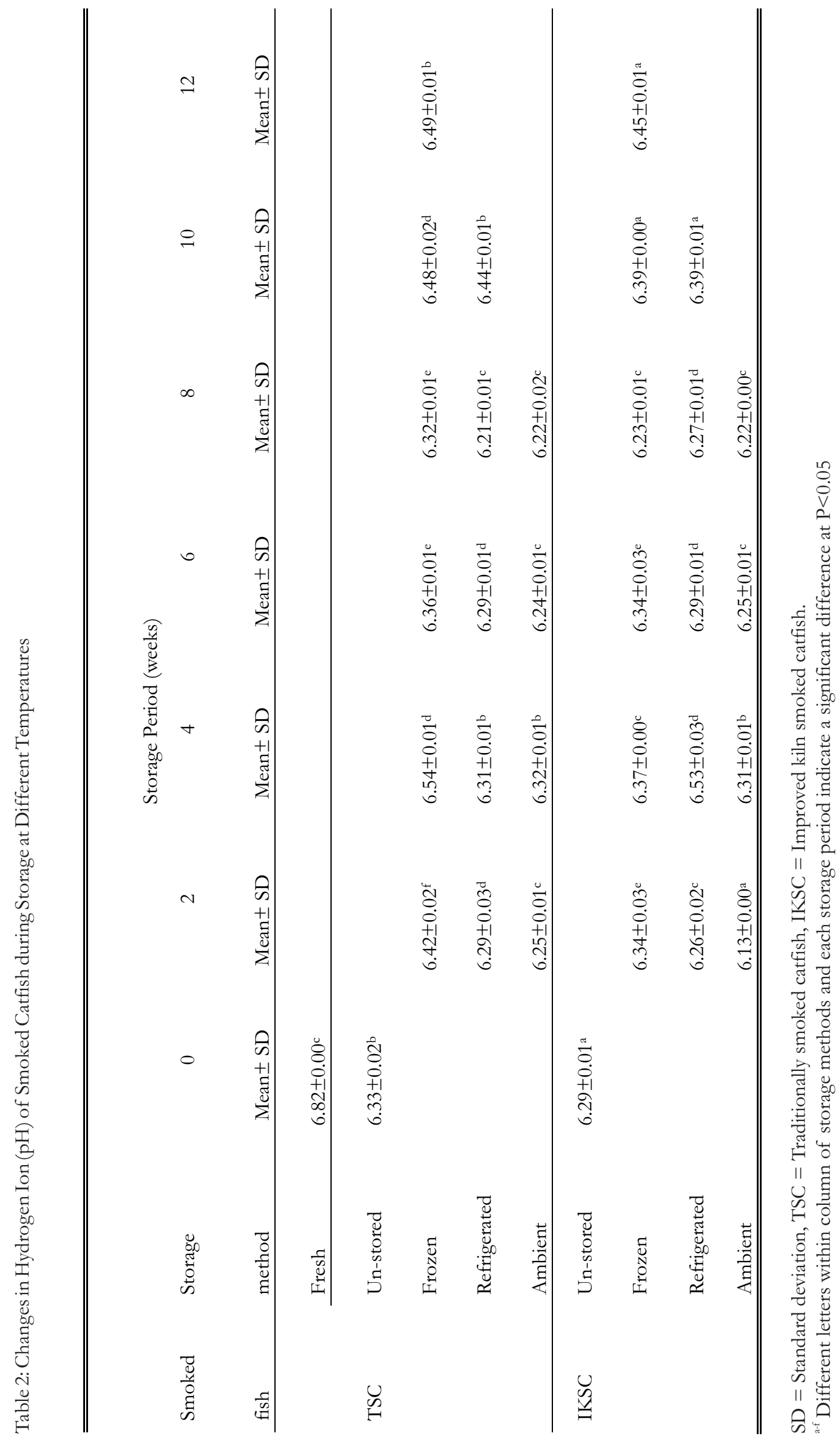




\section{DISCUSSION}

There are so many ways pathogenic organisms can enter a food process and handling at every stage of production determines the quality of the food product. It can be introduced into foods during processing from the environment, air, water, unsanitary utensils, equipment, unclean hands and sewage. It can also be introduced through cross contamination between raw and cooked product (FDA, 2001). Moisture content is a determinant of the quality of dried food products and Clucas (1982) reported that dried fish of $15 \%$ moisture content or less could inhibit microbial growth. It was observed that the moisture content of the smoked catfish in this study fluctuated between 10.00 and $18.00 \%$ during the storage period. The moisture content of the smoked catfish fluctuated during storage as a result of differences in relative humidity and temperature of storage conditions.

The $\mathrm{pH}$ value is an indicator of the degree of freshness or spoilage of food. The $\mathrm{pH}$ of the fresh catfish in this study was quite neutral, dropped after smoking and fluctuated during storage. Nester et al., (2007) reported that a high pH favours microbial growth and that most bacteria will grow best at neutral $\mathrm{pH} 7$ although they can still tolerate ranges from $\mathrm{pH} 5$ (acidic) to $\mathrm{pH} 8$ (basic). The $\mathrm{pH}$ of the smoked catfish from both smoking techniques and the three storage conditions throughout the storage period fall in the range at which most spoilage bacteria will thrive.

The study found out that there was significant reduction in the TVC of the fresh samples to that of smoked fish products from the two smoking techniques. Antonia da Silva et al., (2008) and Salaudeen et al., (2010) also observed reduction in TVC of smoked catfish as a result of hot smoking. Udochukwu et al., (2016) reported decrease in microbial loads of smoked fish as compared to fresh fish of the same species from open markets as a result of smoking effects. The temperature of smoking in the two smoking techniques used in this study was high enough to kill all the viable microorganisms in the freshly smoked products but presence of microorganisms in the freshly smoked (week 0) fish products might be due to post processing contamination during cooling and packaging (FDA, 2001). Greater reduction in TVC of the TSC to that of IKSC despite the higher moisture content of TSC might be due to the higher concentration of phenolic compounds and other smoke derivatives present in the wood smoke compared to that of charcoal which has been burnt off during the production of charcoal. Kester et al., (2013) also reported that phenolic fraction of wood smoke has inhibiting ability on bacteria. The highest TVC recorded in frozen stored samples, followed by the refrigerated stored samples and the least TVC recorded in the ambient stored samples could be attributed to multiplication of the microorganisms as a result of changes in environment and temperatures during the laboratory analysis.

The study recorded presence of Gram negative bacteria Pseudomonas sp. and Aeromonas sp. in the smoked catfish products from both smoking kilns during storage. Pseudomonas and Aeromonas are considered one of the most important fish pathogens (El-Sayyad et al., 2010). GonzálezRodriguez et al., (2002) identified Pseudomonas in vacuum packed cold smoked salmon and trout. It was observed that TVC increased during storage up to the $8^{\text {th }}$ week storage period for smoked fish products from the two smoking techniques. Yanar (2007) also reported increase in TVC of hot smoked catfish during refrigerated storage with time. The increase in TVC might be due to fluctuation in moisture content and $\mathrm{pH}$ of the smoked catfish during storage as a result of changes in relative humidity and temperature. Increase in microbial load over time was also reported by Ikutegbe and Sikoki (2014). TVC is an important factor for quality determination of food products; the maximum recommended bacterial count for good quality products is $5.7 \mathrm{log}$ $\mathrm{CFU} / \mathrm{g}$, and the maximum recommended bacterial count for marginally acceptable quality products is $7 \log \mathrm{CFU} / \mathrm{g}$ (ICMSF 2005).

Penicillium sp. and Aspergillus niger have been identified as important food spoilage moulds. The presence of Penicillium sp. and Aspergillus niger could be as a result of handling during packaging and fluctuation in the moisture content during storage. Martin (1994) reported Penicillium sp and Aspergillus niger as the most common fungi associated with smoked fish. Christianah et al., (2010) also attributed occurrence of Penicillium sp 
and Aspergillus niger to poor processing, handling and reabsorption of moisture during storage.

\section{CONCLUSION}

The study showed a general decline in microbiological safety of smoked fish products from both smoking techniques and the three storage conditions with an observed increase in microbial load over time. The microbial safety and shelf life of stored smoked catfish depends on the smoking technique, storage condition and duration of storage. Therefore, to prevent and minimise health risks to consumers, smoked dried catfish should be hygienically handled, properly stored for short storage period.

\section{ACKNOWLEDGEMENTS}

The authors wish to thank Dr (Mrs) Olajuyigbe, Mrs Udo-Ezika and Rosemary Esangbedo, all of Microbiology unit of the Department of Fish Technology and Product Development, Nigerian Institute for Oceanography and Marine Research (NIOMR), for their support during the analysis.

\section{REFERENCES}

Adeyeye, S.A.O., Oyewole, O.B., Obadina, A.O., Omemu, A. M., Oyedele, H.A. and Adeogun, S.O. (2015). A survey of traditional fish smoking in Lagos State, Nigeria. African Journal of Food Science, 9(2), 59-64.

Antonia da Silva, L. V., Prinyawiwatkul, W., King, J. M., No, H. K., Bankston Jr, J. D., and Ge, B. (2008). Effect of preservatives on microbial safety and quality of smoked blue catfish (Ictalurus furcatus) steaks during room-temperature storage. Food Microbiology, 25, 958-963.

AOAC (1994). Official Methods of Analysis of the Association of Official Analytical Chemists, Vols. I\&II, Association of AnalyticalChemists, Arlington. 1298pp.

Bragadottir, M., Reynisson, E., Thorarinsdottir, K.A. and Arason, S. (2007). Stability of fish powder made from saithe (Pollachinus virens) as measured by lipid oxidation and functional properties. Journal of Aquatic Food Production Technology, 16(1), 211-218.

Christianah, I. A. and Fagade, O.E. (2010): Mycological evaluation of smoked fish
(Ethmalosa fimbriata) from the retail outlets in Ago-Iwoye, Ogun State, Nigeria. Journal of Life and Physical Sciences. 3(2): 64 - 68.

Clucas, I. J. (1982). Fish handling, processing and preservation in the tropics. London: Tropical Products Institute.

Daramola, J. A., Fasakin, E. A. and Adeparusi, E. O. (2007). Changes in physicochemical and sensory characteristics of smokedried fish species stored at ambient temperature. African Journal of Food Agriculture Nutrition and Development, 7(6).

El-Sayyad, H.I., Zaki, V.H., El-Shebly, A.M., and El-Badry, D.A. (2010). Studies on the effects of bacterial diseases on skin and gill structure of Clarias gariepinus in Dakahlia Province, Egypt. Annals of BiologicalResearch, 4: (1) 106-118.

FDA (2001). FDA \& EPA Safety Levels in Regulations and Guidance. In Fish \& Fisheries Products Hazards \& Controls Guidance: $3^{\text {rd }}$ Edition.

FDF (2014). Fisheries Statistics of Nigeria published by Federal Department of Fisheries, Area 11, Garki, Abuja, FCT, Nigeria. (Unpublished)

González-Rodríguez, M., Sanz, J., Santos, J., Otero, J., Garcia-López, M. (2002). Numbers and types of microorganisms in vacuum-packed cold-smoked freshwater fish at the retail level. International Journal of FoodMicrobiology, 77 (1-2): 161-168.

Harrigan, W. (1998). Laboratory methods in food microbiology. Academic press, London, 532pp.

Holt, J. G. (1994). Bergey's Manual of determinative Bacteriology, 9th Edition. Williams and Wilkins, Baltimore. 787pp.

ICMSF. (2005). Fish and Fish Products (Microorganisms in Fish Products). In: Microorganisms in Foods 6. Microbial Ecology of Food Commodities: International Commission on Microbiological Specifications for Foods. Kluwer Academic/Plenum Publishers, New York, USA, pp. 172-249.

Ikutegbe, V. and Sikoki, F. (2014). Microbiological and biochemical spoilage of smoke-dried fishes sold in West African open markets. Food Chemistry 161:332-336.

Joanne M., Willey, L., Sherwood, C. and 
Woolverton, J. (2008). Prescott, Hailey and Klein's Microbiology. McGrawHill, New York. 1088 pp.

Kester, C.T., Daramola, J.A., Oni, P.I. and Oshinaya, S.O. (2013) Effect of Smoking Duration on the Microbiological Quality of Cold-smoked Atlantic Cod, Gadus morbua (Linnaeus, 1758). Journal of Fisheries and Aquatic Science, 8: 196-201.

Kolodziejska, I., Niecikowska, C., Januszewska, E., and Sikorski, Z. (2002). The Microbial and Sensory Quality of Mackerel Hot Smoked in Mild Conditions. Lebensm.Wiss. u.-Technol, 35, 87-92.

Martin, A.M. (1994): Fisheries Processing: Biochemical Applications. Published by Chapman and Hall, London. 1-88pp.

Nester, E., Anderson, D. G., Roberts, C. E., Pearsall, N. N. and Nester, M. T. (2007). Microbiology: A Human Perspective. McGrawHill

NIOMR (2016). Nigerian Institute for Oceanography and Marine Research. Sales record of NIOMR fish smoking kilns. Accessed August, 2016.

Rervik, 2000. Rørvik, L. M. (2000). Listeria monocytogenes in the smoked salmon industry. International Journal of Food Microbiology, 62, 183-190.

Salaudeen, M. M., Akande, G.R., Oguntade, O.R., Afolabi, O.O., Olusola, A.O. and Ezekiel, M.O. (2010). Effect of preservatives on microbial safety and quality of smoked catfish (Clarias gariepinus) during storage. ActaSATECH, Journal of Life and Physical
Sciences 3(2). 81-86.

Simko, P. (2002). Determination of polycyclic aromatic hydrocarbons in smoked meat products and smoke flavouring food additives. Journal of Chromatography B, 770, 3-18.

Stołyhwo, A., and Sikorski, Z. (2005). Polycyclic aromatic hydrocarbons in smoked fish - a critical review. Food Chemistry, 91, 303-311.

Swastawati, F., Suzuki, T., Dewi, E. N., and Winarni, T. (2000). The effect of liquid smoke on the quality and omega-3 fatty acids content of tuna fish (Euthynnus affinis). Journal of Coastal Development, 3, 573-579.

Udochukwu, U., Inetianbor, J., Akaba, S.O and Omorotionmwan, F.O. (2016) Comparative Assessment of the Microbiological Quality of Smoked and Fresh Fish Sold in Benin City and Its Public Health Impact on Consumers. American Journal of Microbiological Research, 4 (1) $37-40$.

Visciano, P., Perugini, M., Conte, F., and Amorena, M. (2008). Polycyclic aromatic hydrocarbons in farmed rainbow trout (Oncorhynchus mykiss) processed by traditional flue gas smoking and by liquid smoke flavourings. Food and Chemical Toxicology, 46, 1409-1413.

Yanar, Y. (2007). Quality changes of hot smoked catfish (Clarias gariepinus) during refrigerated storage. Journal of Muscle Foods, 18:391-400. 